\title{
Effects of Restricted Feeding Molt Diet on Induction of Molt and Energy Intake in Laying Hens
}

\author{
Hnin Yi Soe ${ }^{1}$, Yukihiro Makino², Shinji Mochizuki², Masato Yayota ${ }^{3}$ and Shigeru Ohtani ${ }^{3}$ \\ ${ }^{1}$ United Graduate School of Agricultural Science, Gifu University, Gifu, 501-1193 Japan \\ ${ }^{2}$ Poultry Nutrition Research and Development, Kyodo Shiryo Co., Ltd., Kamisu, 314-0103 Japan \\ ${ }^{3}$ Faculty of Applied Biological Sciences, Gifu University, Gifu, 501-1193 Japan
}

\begin{abstract}
This experiment aimed to determine the effects of restricted feeding a molt diet on molt induction in laying hens. Single Comb White Leghorn hens (age, $61 \mathrm{wk}$ ) were housed in individual cages and randomly divided into 3 groups ( 2 treatments and 1 control group). After a 4-wk preliminary period, the control group was continuously fed a layer ration based on corn and soybean meal ad libitum. Molting was induced in the treatment groups by starvation (MS) or with feeding (MF). In the MS group, the feed was withdrawn for $2 \mathrm{wk}$; this was followed by feeding of the layer ration skip-a-day for $1 \mathrm{wk}$ and then ad libitum. The MF group was fed a low-protein and low-energy diet comprising corn, wheat bran, and corn gluten feed $60 \mathrm{~g} / \mathrm{hen} / \mathrm{d}$ for $4 \mathrm{wk}$; this was followed by ad libitum feeding of the layer ration. Egg production, egg quality, and feed intakes were measured throughout the experimental period; serum estradiol-17 $\beta$ concentration, heterophil: lymphocyte $(\mathrm{H}: \mathrm{L})$ ratio, ovary and oviduct weights, and $\mathrm{ME}_{\mathrm{n}}$ intake were measured during the molting period. During molting, body weights of the MS and MF groups were significantly $(P<0.01)$ reduced than that of the control group. On d 10 of molting, the $\mathrm{H}: \mathrm{L}$ ratio of the MF group was significantly $(P<0.01)$ lower than that of the MS group. On $\mathrm{d} 14$, the ovaries and oviducts of the MS and MF groups were distinctly $(P<0.01)$ lighter than those of the control. On d 6, serum estradiol-17 $\beta$ of the MS and MF groups decreased regardless of the treatment. The energy intake for the MF hens was lower than requirement level and just enough for the basal metabolism. Therefore, the MF hens also completely went out of production during the molting period and arrest period was the same in the MS and MF groups.
\end{abstract}

Key words: energy intake, estradiol, induced molting, molt diet

J. Poult. Sci., 44: 366-374, 2007

\section{Introduction}

Induced molting is used by the poultry industry for optimal economical egg production (Bell, 2003). Brake (1993) stated feed withdrawal as the primary method used by the US poultry industry for inducing molting and stimulating multiple egg-laying cycles in the birds because this method caused the birds to cease egg production for a relatively short period. Further, Webster (2003) stated that the primary objective of an induced molt program is to cause hens to cease egg production and enter a non- reproductive state. The programs used to achieve this objective in commercial flocks may involve feed deprivation for $14 \mathrm{~d}$ or more in warm environments and typically lead to body weight losses of $25 \%$ to $35 \%$.

Recently, the induction of molting by temporary feed withdrawal has been strongly criticized for compromising animal welfare and food safety. The efforts of animal welfare activists to deny market access to eggs obtained from molted flocks lead to a 2000 policy decision by McDonald's Corporation (buys more than 1 billion eggs/y) to implement

Received: March 7, 2007, Accepted: May 9, 2007

Correspondence: Dr. S. Ohtani, Faculty of Applied Biological Sciences, Gifu University, 1-1 Yanagido, Gifu 501-1193, Japan. (E-mail: sohtani@gifu-u.ac.jp) 
against the purchase of eggs from producers that use feed withdrawal as part of their molting programs (Gast and Ricke, 2003). Biggs et al. (2003) indicated that such policies have necessitated the evaluation of alternative non-feed withdrawal methods for the induced molting of laying hens. Moreover, one of the guidelines of the United Egg Producers for inducing molting is "Only non-feed withdrawal molt methods will be permitted after January 1, 2006” (United Egg Producers, 2006).

We have already reported that the group of birds in whom molting was induced by ad libitum feeding fed almost $70 \mathrm{~g} /$ day of the molt diet and not completely stopped egg production during the molting period, and the ratio of heavy eggs (over $76 \mathrm{~g}$ ) in the post-molt period was higher in this group than in the group in which molting was induced by feed withdrawal and in the control group (Hnin Yi Soe et al., 2007). A rest period is essential for improving the post-molt performance of laying hens. Moreover, commercial egg producers often prefer no egg production during the molting period because they use an automatic egg collection system. The molt diet and layer ration that were used in our previous experiment had energy content values of 2.27 and 2.85 $\mathrm{Mcal} / \mathrm{kg}$, respectively; therefore, the energy content of the molt diet was $79 \%$ that of the layer ration. In addition, the feed intake of the group in which molting was induced without feed withdrawal was $69.4 \mathrm{~g} / \mathrm{hen} / \mathrm{d}$ due to ad libitum feeding of the molt diet; the calculated metabolizable energy (ME) intake was greater than the required level, and this may be the primary reason for not completely cessation of egg production during the molt-inducing period. Therefore, this experiment was conducted to determine the effects of the restricted feeding of a molt diet on a molt induction in laying hens from a nutritional viewpoint.

\section{Materials and Methods}

A commercial flock comprising 120 Single Comb White Leghorn hens of the Laura (W-98) strain (age, 61-71 wk) was used in this experiment that was conducted from September to November 2005. The hens were maintained in individual cages in a windowless 2-tier cage house. Individual feeders were used to measure the feed intake of each hen for the ME determination of each hen. There was no restriction on water intake at any time.
The hens were permitted a 4-wk adaptation period. During this period, egg production was monitored to ensure that all the hens were healthy and actively involved in egg production. The lighting cycle was 15L:9D, and all the hens were fed a conventional layer ration based on corn and soybean meal (Table 1) ad libitum. The experimental period comprised a 4-wk molt-inducing period followed by a 2-wk post-molt production period. After the adaptation period, the hens were divided into 3 groups (2 treatment and 1 control group) each consisting of 7 replicates with 5 hens each and with minimal variation with regard to the rate of egg production. During the molt-inducing period, the control group was consistently fed the layer ration ad libitum. Molting was induced in the treatment groups by starvation (MS) or with feeding (MF). In the MS group, the feed was withdrawn for $2 \mathrm{wk}$; this was followed by skip-a-day feeding of the layer ration for $1 \mathrm{wk}$ and then ad libitum. The MF group was fed a low-protein and low-energy molt diet (Table 1) comprising corn, wheat bran, and corn gluten feed

Table 1. Ingredient and composition of diets

\begin{tabular}{lcc}
\hline \hline \multicolumn{1}{c}{ Ingredient and content } & Layer ration & Molt diet \\
\cline { 2 - 2 } Corn & \multicolumn{1}{c}{$\%)$} & \\
\cline { 2 - 3 } Defatted rice bran & 60.600 & 34.500 \\
Wheat bran & 2.000 & 10.000 \\
Corn gluten feed & - & 30.000 \\
Soybean meal & - & 20.000 \\
Rapeseed meal & 14.300 & - \\
Gluten meal & 3.000 & - \\
Fish meal & 4.000 & - \\
Animal fat & 3.000 & - \\
Calcium carbonate & 2.500 & - \\
Dicalcium phosphate & 9.205 & 4.700 \\
Salt & 0.800 & 0.660 \\
DL-methionine & 0.300 & - \\
Choline chloride & 0.055 & - \\
Paprika & 0.040 & 0.040 \\
Vitamin-mineral premix & & - \\
Calculated content $(\%)$ & 0.100 & 0.100 \\
CP & 0.100 & \\
ME (Mcal/kg) & & 13.7 \\
Ca & 17.3 & 2.27 \\
Av. P & 2.85 & 2.11 \\
Na & 4.02 & 0.40 \\
Pa & 0.36 & 0.04
\end{tabular}

${ }^{1}$ Provided per kilogram of diet: vitamin A, $8000 \mathrm{IU}$; vitamin $\mathrm{D}_{3}$, $1600 \mathrm{IU}$; vitamin $\mathrm{E}, 5 \mathrm{IU}$; vitamin $\mathrm{K}_{3}, 1 \mathrm{mg}$; vitamin $\mathrm{B}_{1}, 0.7 \mathrm{mg}$; vitamin $\mathrm{B}_{2}, 2.5 \mathrm{mg}$; vitamin $\mathrm{B}_{6}, 2.5 \mathrm{mg}$; niacin, $10 \mathrm{mg}$; pantothenic acid, $2 \mathrm{mg}$; folic acid, $0.25 \mathrm{mg}$; vitamin $\mathrm{B}_{12}, 0.003 \mathrm{mg}$; biotin, $0.1 \mathrm{mg}$; manganese, $50 \mathrm{mg}$; zinc, $50 \mathrm{mg}$; copper, $5 \mathrm{mg}$; and iodine, $0.2 \mathrm{mg}$. 
at $60 \mathrm{~g} / \mathrm{hen} / \mathrm{d}$ for $4 \mathrm{wk}$. The light hours were reduced to $12 \mathrm{~h} / \mathrm{d}$. During the post-molt production period, all the groups were fed the layer ration, and the light hours were increased by $1 \mathrm{~h} / \mathrm{wk}$.

During the adaptation and experimental periods, egg production, shell breakage, egg weight, and mortality rate were recorded daily; feed intake and individual body weight (BW) were recorded weekly. The shell thickness (excluding the shell membrane) of 20 eggs from each group was measured weekly. During the molt-inducing period, the number of hens that commenced molting was recorded daily. Blood samples were collected from 10 hens each of the MS and MF groups every alternate day from d 0 to 20 between $10 \mathrm{AM}$ to $12 \mathrm{AM}$. The serum estradiol-17- $\beta$ concentration was measured using a commercially available strip plate estradiol enzyme immunoassay (EIA) kit (Catalog No. 582251, Cayman Chemical Co., Michigan 48108 USA) according to the manufacturer's instructions. On d 10 and 25 , blood samples were collected from 5 hens of each group to determine the $\mathrm{H}: \mathrm{L}$ ratio by using the methods described by McKee and Harrison (1995). The $\mathrm{ME}_{\mathrm{n}}$ intake, ie., the ME determined from the gross energy intake and energy output in excreta and corrected for the amount of nitrogen retained, was measured in 5 hens per group at wk 1, 2, and 4 . The correction factor used was $8.22 \mathrm{kcal} / \mathrm{g}$ nitrogen (Scott et al., 1982). The $\mathrm{ME}_{\mathrm{n}}$ intake was measured by using a total collection procedure for 2 successive d. The gross energy of the feed and in the excreta was determined using a bomb calorimeter (Model P-202 CA-4PJ, Shimadzu Co., Kyoto, Japan) with benzoic acid as a standard; the nitrogen content of the feed and in the excreta was measured (Association of Official Analytical Chemists, 1980). At wk 2, 4 and 6, 5 hens per group were decapitated, and the ovaries and oviducts of each were weighed.

All statistical analyses were subjected to ANOVA using the JMP software (version 5.0.1). The means were compared using Tukey's HSD test (SAS Institute Inc., 2002).

\section{Results}

\section{Feed Intake and Body Weight}

The weekly feed intake is shown in Table 2. At wk 0 , the feed intake among all the groups was not significantly different $(P>0.05)$. At wk 3 , it was $61.3 \mathrm{~g} / \mathrm{hen} / \mathrm{d}$ for the MS group due to the use of the skip-a-day feeding method. During the molting period, the feed intake for the MF group decreased approximately 50\% due to limited feeding with the molt diet. At wk 0 , no significant differences $(P>$ 0.05) were observed among the treatment groups with regard to their BWs (Table 3). The hens of the MS group lost $22.6 \%$ of their original $\mathrm{BW}$ at wk 2, while those of the MF group lost $22.2 \%$ of their original $\mathrm{BW}$ at wk 4 . At the end of the post-molt period, the BW of the hens of the MS and MF groups was approximately $99.9 \%$ and $94.8 \%$ of their original $\mathrm{BW}$, respectively. Thus, the hens of the molted groups had regained nearly all of their lost BW.

\section{Molting and Stress}

The percentage of hens that started molting during the molt-inducing period is indicated in Fig. 1. All the hens of the MS and MF groups started molting on $\mathrm{d} 14$ and 19 , respectively. Irrespective of

Table 2. Effect of induced molting on feed intake of laying hens

\begin{tabular}{|c|c|c|c|c|}
\hline Periods & Control & $\mathbf{M S}^{1)}$ & $\mathrm{MF}^{2)}$ & $P$ \\
\hline (wk) & - & $-(\mathrm{g} / \mathrm{hen} / \mathrm{d})$ & - & \\
\hline 0 & $112.2 \pm 2.3^{3)}$ & $110.3 \pm 4.2$ & $110.4 \pm 2.0$ & NS \\
\hline 1 & $109.0 \pm 0.9^{\mathrm{a}}$ & $0.0 \pm 0.0^{\mathrm{c}}$ & $47.4 \pm 2.7^{\mathrm{b}}$ & $* *$ \\
\hline 2 & $108.1 \pm 2.9^{\mathrm{a}}$ & $0.0 \pm 0.0^{\mathrm{c}}$ & $51.3 \pm 3.4^{\mathrm{b}}$ & $* *$ \\
\hline 3 & $111.4 \pm 1.8^{\mathrm{a}}$ & $61.3 \pm 0.8^{\mathrm{b}}$ & $53.2 \pm 4.2^{\mathrm{c}}$ & $* *$ \\
\hline 4 & $109.6 \pm 3.3^{\mathrm{a}}$ & $106.2 \pm 8.5^{\mathrm{a}}$ & $54.1 \pm 3.1^{\mathrm{b}}$ & $* *$ \\
\hline 5 & $109.0 \pm 4.5$ & $109.9 \pm 6.3$ & $105.6 \pm 2.1$ & NS \\
\hline 6 & $111.0 \pm 4.2^{\mathrm{b}}$ & $115.4 \pm 3.9^{\mathrm{ab}}$ & $117.7 \pm 1.2^{\mathrm{a}}$ & $*$ \\
\hline
\end{tabular}

\footnotetext{
${ }^{1)}$ MS: molting by starvation (0-2 wk).

${ }^{2)}$ MF: molting with the molt diet (0-4 wk).

${ }^{3)}$ Data are presented as the mean $\pm \mathrm{SD}$ of 4 replicates per treatment.

** $P<0.01, * P<0.05$, NS: not significant.

${ }^{\text {abc }}$ Means within a row followed by a common superscript are not significantly different.
} 
Table 3. Effect of induced molting on body weight of laying hens

\begin{tabular}{ccccc}
\hline \hline Periods & Control & MS $^{1)}$ & MF $^{2)}$ & $P$ \\
\hline$($ wk $)$ & $1871 \pm 47^{3)}$ & $1795 \pm 61$ & $1829 \pm 26$ & NS \\
0 & $1932 \pm 42^{\mathrm{a}}$ & $1397 \pm 55^{\mathrm{c}}$ & $1541 \pm 45^{\mathrm{b}}$ & $* *$ \\
1 & $1941 \pm 50^{\mathrm{a}}$ & $1372 \pm 56^{\mathrm{c}}$ & $1510 \pm 58^{\mathrm{b}}$ & $* *$ \\
2 & $1937 \pm 32^{\mathrm{a}}$ & $1564 \pm 66^{\mathrm{b}}$ & $1439 \pm 63^{\mathrm{c}}$ & $* *$ \\
3 & $1938 \pm 38^{\mathrm{a}}$ & $1651 \pm 38^{\mathrm{b}}$ & $1429 \pm 65^{\mathrm{c}}$ & $* *$ \\
4 & $1912 \pm 30^{\mathrm{a}}$ & $1770 \pm 44^{\mathrm{b}}$ & $1645 \pm 51^{\mathrm{c}}$ & $* *$ \\
5 & $1933 \pm 31^{\mathrm{a}}$ & $1810 \pm 58^{\mathrm{b}}$ & $1768 \pm 64^{\mathrm{b}}$ & $* *$ \\
6 & & & \\
\hline
\end{tabular}

${ }^{1)}$ MS: molting by starvation ( $\left.0-2 \mathrm{wk}\right)$.

${ }^{2)}$ MF: molting with the molt diet $(0-4 \mathrm{wk})$.

${ }^{3)}$ Data are presented as the mean \pm SD of 4 replicates per treatment.

$* * P<0.01$, NS: not significant.

${ }^{\text {abc }}$ Means within a row followed by a common superscript are not significantly different.

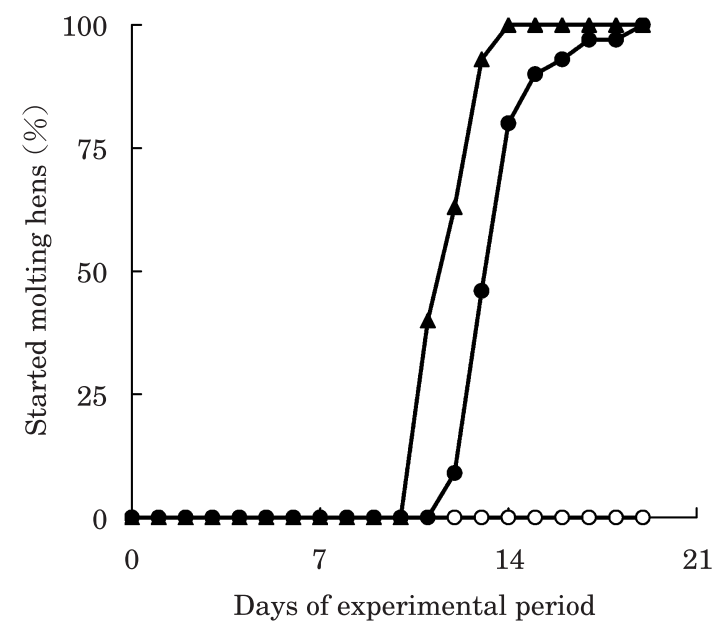

Fig. 1. The percentage of hens that started molting during the molt-inducing period of the control group (O), the hens of molting by starvation (MS: $\boldsymbol{\Delta}$ ), and the hens of molting with the molt diet (MF: $)$ ).

the treatment, the serum estradiol- $17-\beta$ had already decreased in both the treatment groups by d 6 (Fig. $2)$. The serum estradiol-17- $\beta$ concentration in the MS group was the lowest on d 6. Simultaneously, its concentration in the MF group was higher than that in the MS group; but the difference was not statistically significant. It increased in the MS group 2 $\mathrm{d}$ after feeding was resumed. As indicated in Table 4, the reproductive organs of the MS (19.6 g, 1.6\% of the BW) and $\mathrm{MF}(49.0 \mathrm{~g}, 3.4 \%$ of the $\mathrm{BW})$ groups were significantly lighter $(P<0.01)$ than those of the control group $(115.4 \mathrm{~g}, 6.1 \%$ of the BW) at wk 2. In this experiment, the reproductive organs of the molted hens regressed completely during the molt-inducing period; these organs re-

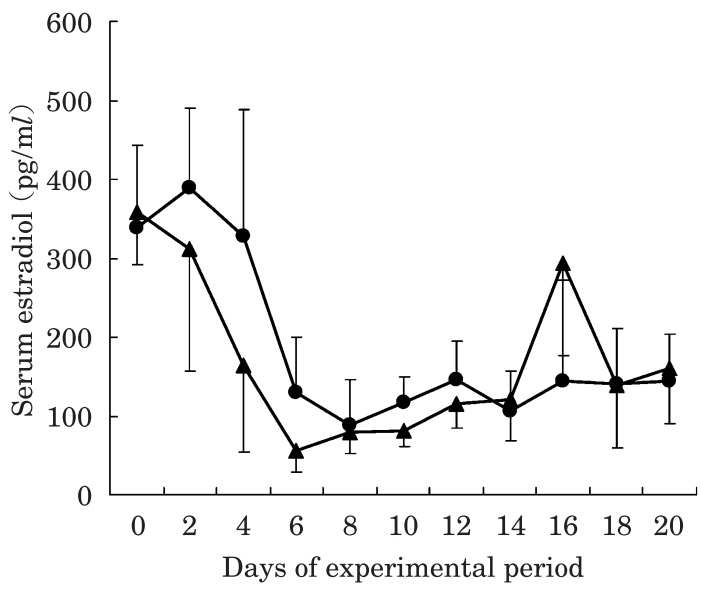

Fig. 2. Effect of induced molting on serum estradiol$17 \beta$ concentration of the hens of molting by starvation (MS: $\boldsymbol{\Delta}$ ), and the hens of molting with the molt diet (MF: $O$ ) groups during the molt-inducing period.

developed when the feeding with normal layer ration was resumed.

The $\mathrm{H}$ : $\mathrm{L}$ ratio, which is used for estimating the level of stressful conditions that result from longterm changes in the environment (Gross and Siegel, 1983), was found to be significantly the highest ( $P$ $<0.01$ ) in the MS group on d 10 (Table 5). In contrast, at d 25, the level was the highest $(P<0.01)$ in the MF group, intermediate in the MS group, and the least in the control group; this may be due to the lower feed intake of the MF hens. Simultaneously, the feed intake of the MF hens was significantly ( $P$ $<0.01)$ lower than that of the control and MS hens. $M E_{\mathrm{n}}$ Intake

The $\mathrm{ME}_{\mathrm{n}}$ intake is summarized in Table 6. The 
Table 4. Effect of induced molting on ovary and oviduct weight of laying hens

\begin{tabular}{|c|c|c|c|c|}
\hline Periods & Control & $\mathbf{M S}^{1)}$ & $\mathrm{MF}^{2)}$ & $P$ \\
\hline (wk) & - & (g) & - & \\
\hline 2 & $115.4 \pm 23.2^{\mathrm{a} 3)}$ & $19.6 \pm 2.7^{\mathrm{b}}$ & $49.0 \pm 27.1^{\mathrm{b}}$ & $* *$ \\
\hline 4 & - & $39.0 \pm 38.3$ & $14.7 \pm 6.3$ & NS \\
\hline 6 & - & - & $101.6 \pm 40.0$ & - \\
\hline (wk) & - & $\%$ (body weight) & (n) & \\
\hline 2 & $6.14 \pm 1.35^{\mathrm{a}}$ & $1.60 \pm 0.23^{\mathrm{b}}$ & $3.41 \pm 1.84^{\mathrm{b}}$ & $* *$ \\
\hline 4 & - & $2.36 \pm 2.29$ & $1.01 \pm 0.53$ & NS \\
\hline 6 & - & - & $5.90 \pm 2.31$ & - \\
\hline
\end{tabular}

${ }^{1)}$ MS: molting by starvation $(0-2 \mathrm{wk})$.

${ }^{2)} \mathrm{MF}$ : molting with the molt diet (0-4 wk).

${ }^{3)}$ Data are presented as the mean $\pm \mathrm{SD}$ of 5 hens per treatment.

** $P<0.01$, NS: not significant.

${ }^{\mathrm{ab}}$ Means within a row followed by a common superscript are not significantly different.

Table 5. Effect of induced molting on heterophil: lymphocyte ratio (H:L ratio)

\begin{tabular}{ccccc}
\hline \hline Periods & Control & $\mathrm{MS}^{1)}$ & $\mathrm{MF}^{2)}$ & $P$ \\
\hline (day) & $-\ldots .0 \pm 5.3^{\mathrm{b} 3)}$ & $42.4 \pm 12.7^{\mathrm{a}}$ & $14.7 \pm 1.7^{\mathrm{b}}$ & $* *$ \\
10 & 9.0 & $13.1 \pm 0.7^{\mathrm{b}}$ & $18.1 \pm 2.4^{\mathrm{a}}$ & $* *$ \\
\hline
\end{tabular}

${ }^{1)}$ MS: molting by starvation ( $\left.0-2 \mathrm{wk}\right)$.

${ }^{2)}$ MF: molting with the molt diet (0-4 wk).

${ }^{3)}$ Data are presented as the mean $\pm \mathrm{SD}$ of 5 hens per treatment.

** $P<0.01$.

${ }^{\text {abc }}$ Means within a row followed by a common superscript are not significantly different.

Table 6. Effect of induced molting on $\mathbf{M E}_{\mathbf{n}}$ intake of laying hens

\begin{tabular}{|c|c|c|c|c|}
\hline Periods & Control & $\mathbf{M S}^{1)}$ & $\mathrm{MF}^{2)}$ & $P$ \\
\hline (wk) & - & (kcal/hen/day) & (n) & \\
\hline 1 & $314.2 \pm 16.6^{\mathrm{a} 3)}$ & - & $90.6 \pm 15.4^{\mathrm{b}}$ & $* *$ \\
\hline 2 & $294.3 \pm 44.4^{\mathrm{a}}$ & - & $106.2 \pm 12.5^{\mathrm{b}}$ & $* *$ \\
\hline 4 & $329.2 \pm 27.7^{\mathrm{a}}$ & $277.7 \pm 38.4^{\mathrm{a}}$ & $103.4 \pm 16.0^{\mathrm{b}}$ & $* *$ \\
\hline (wk) & (n & $\left(\mathrm{kcal} / \mathrm{kg}^{0.75} /\right.$ day $)$ & & \\
\hline 1 & $189.8 \pm 5.5^{\mathrm{a}}$ & - & $64.6 \pm 12.8^{\mathrm{b}}$ & $* *$ \\
\hline 2 & $177.4 \pm 19.3^{\mathrm{a}}$ & - & $76.5 \pm 10.2^{\mathrm{b}}$ & $* *$ \\
\hline 4 & $200.5 \pm 13.9^{\mathrm{a}}$ & $194.9 \pm 39.8^{\mathrm{a}}$ & $78.5 \pm 11.7^{\mathrm{b}}$ & $* *$ \\
\hline
\end{tabular}

${ }^{1)}$ MS: molting by starvation ( $\left.0-2 \mathrm{wk}\right)$.

${ }^{2)}$ MF: molting with the molt diet (0-4 wk).

${ }^{3)}$ Data are presented as the mean $\pm \mathrm{SD}$ of 5 hens per treatment.

** $P<0.01$.

${ }^{\mathrm{ab}}$ Means within a row followed by a common superscript are not significantly different.

mean energy intake of the MF group was significantly $(P<0.01)$ lower than that of the control group. However, there was no significant difference in this value between the control and MS groups at wk 4. The ME values of the experimental diets were calculated based on the quantities of feed intake and energy intake of each hen. The ME value of the layer ration was $2.95 \pm 0.05 \mathrm{Mcal} / \mathrm{kg}$ for the control group and $2.91 \pm 0.02 \mathrm{Mcal} / \mathrm{kg}$ for the MS group. The ME value of the molt diet was $2.12 \pm 0.11$ Mcal $/ \mathrm{kg}$. These values were approximately the same as the previously calculated ME values (Table 1) of the layer ration $(2.85 \mathrm{Mcal} / \mathrm{kg})$ and molt diet (2.27 Mcal $/ \mathrm{kg})$.

Egg Production, Egg Weight, and Shell Thickness

The daily and weekly rates of egg production 
(excluding egg breakage) are presented in Fig. 3 and Table 7, respectively. The hens in the MS and MF groups completely ceased egg production by $\mathrm{d} 6$ and 12 until d 31 and 37, respectively. In this experiment, the experimental post-molt egg production period was only $2 \mathrm{wk}$. This period was just at the beginning of the second laying cycle of the molted hens. Therefore, in this period, the egg production of the molted hens was lower than that of the control hens (Table 7); but at d 44, the egg production was not significantly different between the groups (Fig. 3). Throughout the experimental period, the egg weight for the control group tended to

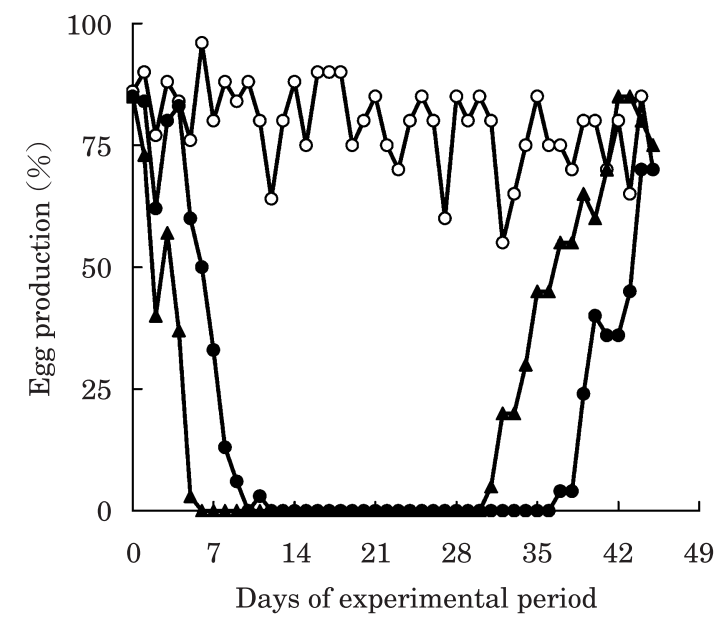

Fig. 3. Daily egg production (excluding egg breakage) during the molt-inducing and post-molt periods of the hens of control group ( $\bigcirc$ ), the hens of molting by starvation (MS: $\Delta$ ), and the hens of molting with the molt diet (MF: $\bigcirc)$. increase with age (Table 8). At wk 0 , no significant $(P>0.05)$ differences with regard to egg weight and shell thickness were observed among the treatment groups. However, at wk 6, the shell thickness of the MS and MF groups was significantly improved $(P<$ 0.01 ) as compared to the control group (Table 9).

\section{Discussion}

\section{Indicators of Molt Effectiveness}

The physiological responses (weight loss in hens, feather molting, and complete cessation of egg laying) that occur during traditional molting are used as indicators of molt effectiveness. These responses are considered as the important factors for improving the post-molt performance. However, the key factor for improving post-molt egg quality is the regression and rejuvenation of the cells lining the reproductive tract (Brake and Thaxton, 1979).

In this experiment, the maximum BW loss was $22.6 \%$ and $22.2 \%$ in the MS (at wk 2) and MF (at wk 4) groups, respectively, and these values were nearly the same in both the groups. The loss of primary feathers is clearly due to the loss of estrogen influence on feather papillae (Peczely, 1992); therefore, molting occurs during a nadir in estrogen production (Brake, 1993). The first significant effect of molting, regardless of the method used, is a decrease in the serum estradiol-17- $\beta$ concentration to approximately half its pretreatment value (Fig. 2 ). This decrease coincides with the decrease in egg production. Our findings are in agreement with those of Tanabe et al. (1982), Hoshino et al. (1988), and Braw-Tal et al. (2004). The ovary and oviduct

Table 7. Effect of induced molting on egg production ${ }^{1)}$ of laying hens

\begin{tabular}{ccccc}
\hline \hline Periods & Control & $\mathrm{MS}^{2)}$ & $\mathrm{MF}^{3)}$ & $P$ \\
\hline$($ wk $)$ & $\cdots \ldots \ldots \ldots \ldots$ & \\
0 & $82.0 \pm 2.9^{4)}$ & $85.4 \pm 5.4$ & $85.4 \pm 5.4$ & $\mathrm{NS}$ \\
1 & $83.6 \pm 7.9^{\mathrm{a}}$ & $32.1 \pm 4.9^{\mathrm{c}}$ & $66.4 \pm 4.3^{\mathrm{b}}$ & $* *$ \\
2 & $82.2 \pm 5.9^{\mathrm{a}}$ & $0.0 \pm 0.0^{\mathrm{b}}$ & $2.2 \pm 1.4^{\mathrm{b}}$ & $* *$ \\
3 & $83.6 \pm 5.4^{\mathrm{a}}$ & $0.0 \pm 0.0^{\mathrm{b}}$ & $0.0 \pm 0.0^{\mathrm{b}}$ & $* *$ \\
4 & $76.4 \pm 5.9^{\mathrm{a}}$ & $0.0 \pm 0.0^{\mathrm{b}}$ & $0.0 \pm 0.0^{\mathrm{b}}$ & $* *$ \\
5 & $75.0 \pm 14.1^{\mathrm{a}}$ & $17.1 \pm 9.9^{\mathrm{b}}$ & $0.0 \pm 0.0^{\mathrm{b}}$ & $* *$ \\
6 & $75.7 \pm 7.6^{\mathrm{a}}$ & $62.1 \pm 12.2^{\mathrm{a}}$ & $21.4 \pm 19.9^{\mathrm{b}}$ & $* *$
\end{tabular}

\footnotetext{
${ }^{1)}$ Not including egg breakage (broken, cracked, soft and shell-less eggs).

${ }^{2)}$ MS: molting by starvation ( $\left.0-2 \mathrm{wk}\right)$.

${ }^{3)} \mathrm{MF}$ : molting with the molt diet (0-4 wk).

4) Data are presented as the mean \pm SD of 4 replicates per treatment.

** $P<0.01$, NS: not significant.

${ }^{a b c}$ Means within a row followed by a common superscript are not significantly different.
} 
Table 8. Effect of induced molting on egg weight of laying hens

\begin{tabular}{ccccc}
\hline \hline Periods & Control & $\mathrm{MS}^{1)}$ & $\mathrm{MF}^{2)}$ & $P$ \\
\hline$($ wk $)$ & $-\ldots \ldots$ & $(\mathrm{g}) \cdots \ldots .7$ & \\
0 & $66.3 \pm 1.9^{3)}$ & $65.1 \pm 1.7$ & $65.4 \pm 0.6$ & $\mathrm{NS}$ \\
1 & $67.8 \pm 1.7^{\mathrm{a}}$ & $63.2 \pm 1.5^{\mathrm{b}}$ & $64.1 \pm 1.1^{\mathrm{b}}$ & $* *$ \\
2 & $68.3 \pm 1.8^{\mathrm{a}}$ & - & $61.2 \pm 0.9^{\mathrm{b}}$ & $* *$ \\
3 & $68.5 \pm 1.7$ & - & - & - \\
4 & $68.9 \pm 2.3$ & - & - & $*$ \\
5 & $69.1 \pm 1.5^{\mathrm{a}}$ & $62.9 \pm 0.7^{\mathrm{b}}$ & - & $\mathrm{NS}$ \\
6 & $69.3 \pm 2.0$ & $67.2 \pm 0.4$ & $62.4 \pm 6.7$ & \\
\hline
\end{tabular}

${ }^{1)}$ MS: molting by starvation (0-2 wk).

${ }^{2)}$ MF: molting with the molt diet $(0-4 \mathrm{wk})$.

${ }^{3)}$ Data are presented as the mean \pm SD of 4 replicates per treatment.

$* * P<0.01$, NS: not significant.

${ }^{\mathrm{ab}}$ Means within a row followed by a common superscript are not significantly different.

Table 9. Effect of induced molting on egg shell thickness ${ }^{1)}$ of laying hens

\begin{tabular}{|c|c|c|c|c|}
\hline Periods & Control & $\mathrm{MS}^{2)}$ & $\mathrm{MF}^{3)}$ & $P$ \\
\hline (wk) & 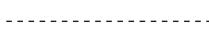 & $(\mathrm{mm})$ & . & \\
\hline 0 & $0.353 \pm 0.025^{4)}$ & $0.349 \pm 0.022$ & $0.349 \pm 0.015$ & NS \\
\hline 1 & $0.335 \pm 0.028$ & $-^{5)}$ & $0.328 \pm 0.011$ & NS \\
\hline 2 & $0.352 \pm 0.024$ & - & $-^{5)}$ & - \\
\hline 3 & $0.350 \pm 0.025$ & - & - & - \\
\hline 4 & $0.350 \pm 0.023$ & - & - & - \\
\hline 5 & $0.351 \pm 0.041$ & $0.372 \pm 0.039$ & - & NS \\
\hline 6 & $0.335 \pm 0.035^{\mathrm{b}}$ & $0.366 \pm 0.025^{\mathrm{a}}$ & $0.374 \pm 0.031^{\mathrm{a}}$ & $* *$ \\
\hline
\end{tabular}

${ }^{1)}$ Average of egg shell thickness (3 places of central part).

${ }^{2)}$ MS: molting by starvation (0-2 wk).

${ }^{3)}$ MF: molting with the molt diet (0-4 wk).

${ }^{4)}$ Data are presented as the mean $\pm \mathrm{SD}$ of 4 replicates per treatment.

${ }^{5)}$ Egg production was zero at the day of egg quality measured.

$* * P<0.01$, NS: not significant.

${ }^{\mathrm{ab}}$ Means within a row followed by a common superscript are not significantly different.

regress during induced molting, and then redevelop by the time egg laying resumes. In this experiment, regression of the reproductive organs during the molting period was observed in the hens from both the MS and MF groups (Table 4). This finding confirms the earlier findings of Seo et al. (2001) and Biggs et al. (2004). The MS group was starved for $2 \mathrm{wk}$, and the MF group was fed the molt diet for 4 wk. As shown in Table 4, 2 wk after re-feeding with the normal layer ration, the reproductive organs redeveloped in most of the hens of the MF group; however, this redevelopment had not yet to occur in most of the hens of the MS group. The duration of the rest period, during which egg production ceased completely was the same for the MS and MF groups (Fig. 3).

These results clearly indicated that the MF hens lead to be molting similar to the MS hens.

\section{Energy Intake and Requirement}

Animals reared for productive purposes must be fed to maintain life irrespective of whether they are actively producing or not. A considerable part of the feed consumed by all classes of poultry must be used for their maintenance. The maintenance energy requirement includes the energy needed for basal metabolism and normal activity (Austic and Nesheim, 1990). Body size affects maintenance energy requirements. Data collected from non-passerine birds showed that the energy needed for the basal metabolism was equal to $78.3 \mathrm{kcal} /$ day $\times(\mathrm{kg}$ BW) ${ }^{0.723}$ (Lasiewski and Dawson, 1967). Therefore, the $\mathrm{ME}_{\mathrm{n}}$ intake of the MF group during induced molting in our experiment was just adequate for basal metabolism, as shown in Table 6. Furthermore, the ME requirement (National Agriculture and Bio-oriented Research Organization, 2004) for 
Table 10. Metabolizable energy requirement ${ }^{1)}$ and energy intake of MF hens during molting period

\begin{tabular}{cccccrrrr}
\hline \hline \multirow{2}{*}{$w k$} & $\begin{array}{c}\mathrm{T}^{2)} \\
{ }^{\circ} \mathrm{C}\end{array}$ & \multicolumn{1}{c}{$\mathrm{W}{ }^{3)}$} & $\begin{array}{c}\mathrm{EM}^{4)} \\
\mathrm{gg}\end{array}$ & $\begin{array}{c}\Delta \mathrm{W}^{5)} \\
\mathrm{g} / \text { day }\end{array}$ & $\begin{array}{c}\text { ME Requirement } \\
\mathrm{kcal} / \text { day }\end{array}$ & $\begin{array}{c}\text { Feed Intake } \\
\mathrm{g} / \text { day }\end{array}$ & $\begin{array}{c}\text { ME Intake }^{6)} \\
\mathrm{kcal} / \text { day }\end{array}$ & $\begin{array}{c}\text { Sufficiency Rate }^{7)} \\
(\%)\end{array}$ \\
\hline 1 & $21.5 \pm 0.6^{8)}$ & $1.58 \pm 0.11$ & $42.3 \pm 9.4$ & $-37.8 \pm 6.6$ & $174.2 \pm 14.8$ & $43.5 \pm 7.2$ & $94.6 \pm 16.0$ & $55 \pm 13$ \\
2 & $17.8 \pm 2.0$ & $1.55 \pm 0.06$ & $1.7 \pm 3.9$ & $-4.6 \pm 8.6$ & $158.9 \pm 13.2$ & $52.3 \pm 8.4$ & $108.7 \pm 13.5$ & $68 \pm 4$ \\
4 & $13.8 \pm 0.9$ & $1.44 \pm 0.04$ & $0.0 \pm 0.0$ & $-5.6 \pm 4.3$ & $150.5 \pm 9.3$ & $51.3 \pm 11.0$ & $106.8 \pm 17.3$ & $71 \pm 9$ \\
\hline
\end{tabular}

${ }^{1)} \mathrm{ME}$ requirement $(\mathrm{kcal} / \mathrm{hen} /$ day $)=110 \times \frac{-0.081 \times(22-T)^{2}+2 \times(22-T)+94}{94} \times \mathrm{W}^{0.75}+2.2 \times \mathrm{E}$ mass $+2 \times \Delta \mathrm{W}$.

2) Temperature inside the hen house.

${ }^{3)}$ Body weight in kilograms.

4) Egg mass (average daily egg production in grams).

${ }^{5)}$ The change in body weight in grams per day.

${ }^{6)}$ Calculated from gross energy of feed and feces from five hens.

${ }^{7)} \mathrm{ME}$ Intake/ME Requirement $\times 100$.

${ }^{8)}$ Mean \pm SD.

the $\mathrm{MF}$ group was also calculated. The ME requirement and ME intake of the MF group during the molting period are presented in Table 10. The ME intake was relatively lower than the ME requirement for the MF group; hence, similar to the MS group, egg production completely ceased during the molting period. Our results were in agreement with those reported by Keshavarz and Quimby (2002) and Biggs et al. (2003, 2004). This indicated that the low-energy molt diet worked well for inducing molting in laying hens.

Thus, it is now clear that feeding with the molt diet $(60 \mathrm{~g} / \mathrm{hen} / \mathrm{d})$ may cause the hens to completely cease egg production. However, the feasibility of this practice for rearing of commercial flocks is questionable due to the following factors: the use of automatic feeding systems, capacities of poultry houses for the accommodation of large flocks, and the existence of multiple hen cages with hens of different social ranks within a cage. Nevertheless, our results can be used to evaluate the effects of the molt diet on induced molting. Further research will be conducted to determine the effects of a molt diet comprising other ingredients and to determine methods to reduce the energy level of the molt diet in order to maximize molt induction and the postmolt egg quality.

\section{References}

Association of Official Analytical Chemists. Official Methods of Analysis. $13^{\text {th }}$ ed. Association of Official Analytical Chemist. Washington, DC. 1980.

Austic RE and Nesheim MC. Biology of domestic fowl. In: Poultry production. $13^{\text {th }}$ ed. pp. 19-60. Lea and Febiger, Philadelphia. London. 1990.
Bell DD. Historical and current molting practices in the US table egg industry. Poultry Science, 82: 965-970. 2003.

Biggs PE, Douglas MW, Koelkebeck KW and Parsons CM. Evaluation of nonfeed removal methods for molting programs. Poultry Science, 82: 749-753. 2003.

Biggs PE, Persia ME, Koelkebeck KW and Parsons CM. Further evaluation of nonfeed removal methods for molting programs. Poultry Science, 83: 745-752. 2004.

Brake $\mathbf{J}$ and Thaxton P. Physiological changes in caged layers during a forced molt. 2. Gross changes in organs. Poultry Science, 58: 707-716. 1979.

Brake J. Recent advances in induced molting. Poultry Science, 72: 929-931. 1993.

Braw-Tal R, Yossefi S, Pen S, Shinder D and Bar A. Hormonal changes associated with ageing and induced moulting of domestic hens. British Poultry Science, 45: 815822. 2004.

Gast RK and Ricke SC. Symposium: Current and future prospects for induced molting in laying hens. Poultry Science, 82: 964. 2003.

Gross WB and Siegel HS. Evaluation of heterophil/lymphocyte ratio as a measure of stress in chickens. Avian Diseases, 27: 972-979. 1983.

Hnin Yi Soe, Makino Y, Uozumi N, Yayota M and Ohtani S. Evaluation of non-feed removal induced molting in laying hens. Journal of Poultry Science, 44: 153-160. 2007.

Hoshino S, Suzuki M, Kakegawa T, Imai K, Wakita M, Kobayashi Y and Yamada Y. Changes in plasma thyroid hormones, luteinizing hormone $(\mathrm{LH})$, estradiol, progesterone and corticosterone of laying hens during a forced molt. Comparative Biochemistry and Physiology, 90A: 355-359. 1988.

Keshavarz K and Quimby FW. An investigation of different molting techniques with an emphasis on animal welfare. Journal of Applied Poultry Research, 11: 54-67. 2002.

Lasiewski RC and Dawson WR. A re-examination of the relation between standard metabolic rate and body weight in birds. Condor, 69: 13-23. 1967.

McKee JS and Harrison PC. Effects of supplemental ascorbic acid on the performance of broiler chickens exposed to 
multiple concurrent stressors. Poultry Science, 74: 17721785. 1995.

National Agriculture and Bio-oriented Research Organization. Japanese feeding standard for poultry (2004). pp. 3-11. Japan Livestock Industry Association. 2004. (in Japanese).

Peczely P. Hormonal regulation of feather development and molting on the level of feather follicles. Ornis Scandinavica, 23: 346-354. 1992.

SAS Institute Inc., One-Way ANOVA. In: JMP Statistics and Graphic Guide, version 5. pp. 89-126. SAS Institute Inc., Cary, NC, USA. 2002.

Scott ML, Nesheim MC and Young RJ. Determination of metabolizable energy. In: Nutrition of the Chicken. Third Edition. pp. 535-539. ML Scott and Associates,
Ithaca, NY. 1982.

Seo K-H, Holt PS and Gast RK. Comparison of Salmonella Enteritidis infection in hens molted via long-term feed withdrawal versus full-feed wheat middling. Journal of Food Protection, 64: 1917-1921. 2001.

Tanabe H, Nakamura T and Tanabe Y. Endocrine mechanism of ovarian follicular atresia caused by fasting of the hen. In: Aspects of Avian Endocrinology: Practical and Theoretical Implications (Scanes CG et al., eds.) pp. 191-199. Texas Tech Press. Lubbock, Tex. 1982.

United Egg Producers. Molting. In: Animal Husbandry Guidelines for U.S Egg Laying Flocks. 2006 Edition. pp. 9-10. Alpharetta, GA. 2006.

Webster AB. Physiology and behavior of the hen during induced molt. Poultry Science, 82: 992-1002. 2003. 